\title{
NOTES
}

\section{WHITMAN'S 1855 LEAVES OF GRASS: ANOTHER CONTEMPORARY VIEW}

On 21 July 1855 Ralph Waldo Emerson penned a letter of praise and congratulations to a young New York poet and journeyman printer named Walter Whitman. The writing and eventual printing of this letter was destined to become, in the words of Emerson's biographer, "an event of greater importance in the history of American literature than the printing of any other letter has ever been."1 Whitman's publication of this letter is considered to have been an embarrassment to Emerson because he apparently intended it as private encouragement rather than public endorsement and also, perhaps, because he had not succeeded in arousing his friends and acquaintances to a full appreciation of this vigorous and highly unorthodox work. ${ }^{2}$ In fact, the responses to Whitman's work in Emerson's circle were varied to say the least, ranging from silence to hostility, and, finally, to something bordering on confusion.

It is known that on several occasions Emerson touted Whitman's positive cualities as an authentic American poet but often garnered little response. For example, in a letter to his lifelong friend William Henry Furness in October 1855 Emerson inquired, "Have you read that wonderful book-with all its formlessness \& faults 'Leaves of Grass'?"3 Furness's fragmentary response makes no mention of Whitman. Similarly, in a letter to Carlyle somewhat later Emerson states, "One book, last summer, came out in New York, a nondescript monster which yet has terrible eyes \& buffalo strength, \& was indisputably American." Emerson goes on to say that he had intended to send a copy of the book to Carlyle but, "it throve so badly with the few to whom I showed it \& wanted good morals so much, that I never did. Yet I believe now again, I shall." 4 Despite this positive overture, however, there is no record of Carlyle's epistolary response. Nevertheless, he did at one point indicate his opinion of Whitman to another by noting that, "It was as though the town-bull had learned to hold a pen." 5

The moral question which Emerson alludes to in his letter to Carlyle undoubtedly played a large part in the tepid response of many to Whitman. Thus J. P. Lesley of Philadelphia in a letter to Emerson dated 25 November 1855 noted that he had examined the "profane \& obscene" Leaves of Grass and thought the author a pretentious ass without decency. The purpose of the letter was to confirm that a newspaper article containing Emerson's enthusiastic endorsement of the work was "a malicious jest." Along somewhat similar lines Emerson once noted in his journal that "Whipple [a contemporary essayist and critic] said of the author of 'Leaves of Grass,' that he had every leaf but the fig leaf." "

Despite these negative reactions, however, Emerson continued to recommend Leaves of Grass to his friends and acquaintances with the hope, apparently, that others would come to see the poet's positive qualities. In some cases he succeeded. Probably the most notable of these is Henry David Thoreau. After traveling to New York with Bronson Alcott to meet Whitman in 1856 Thoreau, in a letter to a friend, expresses some reservations about "two or three pieces in the book [Leaves of 
Grass] which are disagreeable" but on the whole feels Whitman "has spoken more truth than any American or modern I know" and that "we ought to rejoice greatly in him." Whitman found another enthusiastic reader in the person of Franklin Sanborn, Emerson's friend and Concord neighbor and a man destined to become an author of minor repute. Sanborn thought highly of Whitman as both a poet and a person and wrote warmly of his subsequent visits to Concord. ${ }^{9}$

On some occasions, however, Emerson's attempts to find an audience for Leaves of Grass resulted in neither hostility nor enthusiasm, but something more akin to confusion. The most significant among these is James Elliot Cabot. As the friend who was destined to become Emerson's editor, literary executor and, finally, biographer, Cabot was undoubtedly a person whose literary opinion Emerson valued. It is not surprising then that Cabot was among the first whose reactions Emerson would solicit regarding the poet Walt Whitman. Accordingly, in a letter to Cabot dated 26 September 1855 Emerson describes Whitman as a "Mirabeau of a man, with such insight \& equal expression" and notes that it was his intention "many weeks ago" to forward a copy of Leaves of Grass to his friend but assumed because the poems had since "become more known" that Cabot had already come across them. ${ }^{10}$ Apparently Cabot replied promptly that he had not yet seen the book, which in turn led Emerson to make a loan of his copy.

Cabot's reaction to the work, contained in a letter which is printed here for the first time, must have come as something of a disappointment to Emerson. While Cabot did not take umbrage, as many of his New England contemporaries did, at Whitman's sensuality, and while he did recognize the subtle similarity between some aspects of Whitman's philosophical outlook and Emerson's, it is clear that on the whole Whitman's brash work of original genius left him somewhat confused and uncertain. ${ }^{11}$

\section{My dear Emerson,}

November 5, 1855

I return with many thanks the "Leaves of Grass" which as a new book I ought not to have kept so long. - Certainly there's somebody there, though whether he be a poet or not I have not sufficient judgement to say.

He has some of the pre requisites certainly certainly [sic?] - first of all he is a thorough-going "evident-destiny" man-then his insight into things about him (which seems considerable) take [sic] the shape of concrete things.

Nevertheless I shall say he was more of a philosopher than a poet \& more a Hindoo philosopher, or what I once shocked you, I believe, by calling "a skeptic"-meaning not at all a doubter, but a skeptic in the ancient, SEXTUS EMPERICUS way, i.e. a firm believer in Chaos, or the Everlasting No. - His optimism, his universal equality (sand.grain = the universe) the last first \& first last; his unlimited enumeration; \& overflow of adjectives \& substantives - his alternate identification of himself with all mankind, \& separation of himself from himself-all this I translate as the endeavor after expression of one who has caught a glimpse of one side of the circle, \& sees that all Reality is Spirit, but does not yet suspect the other one, that Spirit is all Reality - But however that may be, he seems to me to know too much about poetry to afford any prospect of being a poet himself. But we can use him, whichever he be, if there's really anything there, beyond a prognostic \& an echo. There's a good deal of echo about him, \& many of his good things you may recognize as very intimate acquaintances.

I like the preface best, \& very well. But in the poem I do not see much advance toward 
the solution of the problem which he very well puts to the poet, viz, "to indicate the path between reality \& the souls of men"-he seems to be oppressed with the reality of the soul, \& to be constantly running back $\&$ forth between them, counting, demonstrating-but the magic stroke that should make them one, is wanting. - These things I say de bene esse without any pretense to judgement in these matters, \& the more freely [?] on that account.

I hope you will pardon this hasty scrap, rather jammed between two journies. I dare not keep your book any longer.

Very truly yours,

J. Elliot Cabot

Despite the mixed responses to Leaves of Grass which Emerson garnered from those around him his respect for the work was enduring and he continued to recommend it enthusiastically. Thus several years after his initial acquaintance with the book Emerson felt no reluctance in issuing the following advice to a group of young men who were eager to learn what literature they should read. "'Leaves of Grass,' by Walt Whitman, is a book you must certainly read. It is wonderful."12

University of Scranton

LEN GOUGEON

\section{NOTES}

1 Ralph Rusk, editor, The Letters of Ralph Waldo Emerson (New York: Columbia University Press, 1939), 4:520.

2 For Emerson's reaction to the printing of the letter see Franklin Sanborn, "Whitman and Emerson," 1897. Reprinted in Kenneth W. Cameron, editor, Transcendental and Literary New England (Hartford: Transcendental Books, 1975), p. 203.

3 Horace Howard Furness, editor, Records of a Lifelong Friendship: 1807-1882 Ralph Waldo Emerson and William Henry Furness (Boston: Houghton Mifflin Company, 1910), p. 107.

4 Joseph Slater, editor, The Correspondence of Emerson and Carlyle (New York: Columbia University Press, 1964), p. 509.

5 David A. Wilson and David W. MacArthur, Carlyle in Old Age (London: Kegan Paul, Trench, Trübner \& Co., Ltd., 1934), p. 261.

6 Rusk, Letters, 4:520.

7 Susan Sutton Smith and Harrison Hayford, editors, The fournals and Miscellaneous Notebooks of Ralph Waldo Emerson (Cambridge: Harvard University Press, 1978), $14: 74$.

8 Perry Miller, editor, The American Transcendentalists: Their Prose and Poetry (New York: Doubleday \& Company, Inc., 1957), p. 369.

9 Franklin Sanborn, "Whitman and Emerson," pp. $202 \mathrm{ff}$.

10 Rusk, Letters, 4:531.

11 Letter from James Elliot Cabot to Ralph Waldo Emerson, 5 November 1855, MS, Schlesinger Library, Radcliffe College.

12 Charles Woodbury, Talks with Ralph Waldo Emerson (London: Kegan Paul, Trench, Trübner \& Co., Ltd., 1890), p. 63. 